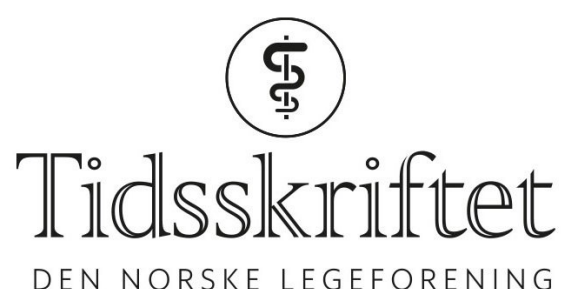

\title{
Helgenen som ble kokt levende
}

TIDLIGERE I TIDSSKRIFTET

\section{JULIE DIDRIKSEN}

E-post: julie.didriksen@tidsskriftet.no Tidsskriftet

På forsiden av utgave 16/1994 finner vi den kristne helgenen Sankt Vitus. Han regnes blant annet som skytshelgen for skuespillere, komikere, dansere og folk med epilepsi. Som en av nødhjelperne har han en spesiell posisjon blant helgener ved at man skulle kunne henvende seg til han om man var i nød, særlig ved kramper og nervesykdommer (Tidsskr Nor Lægeforen 1994; 114: 1793, 1795).

St. Vitus - en av nødhjelperne 


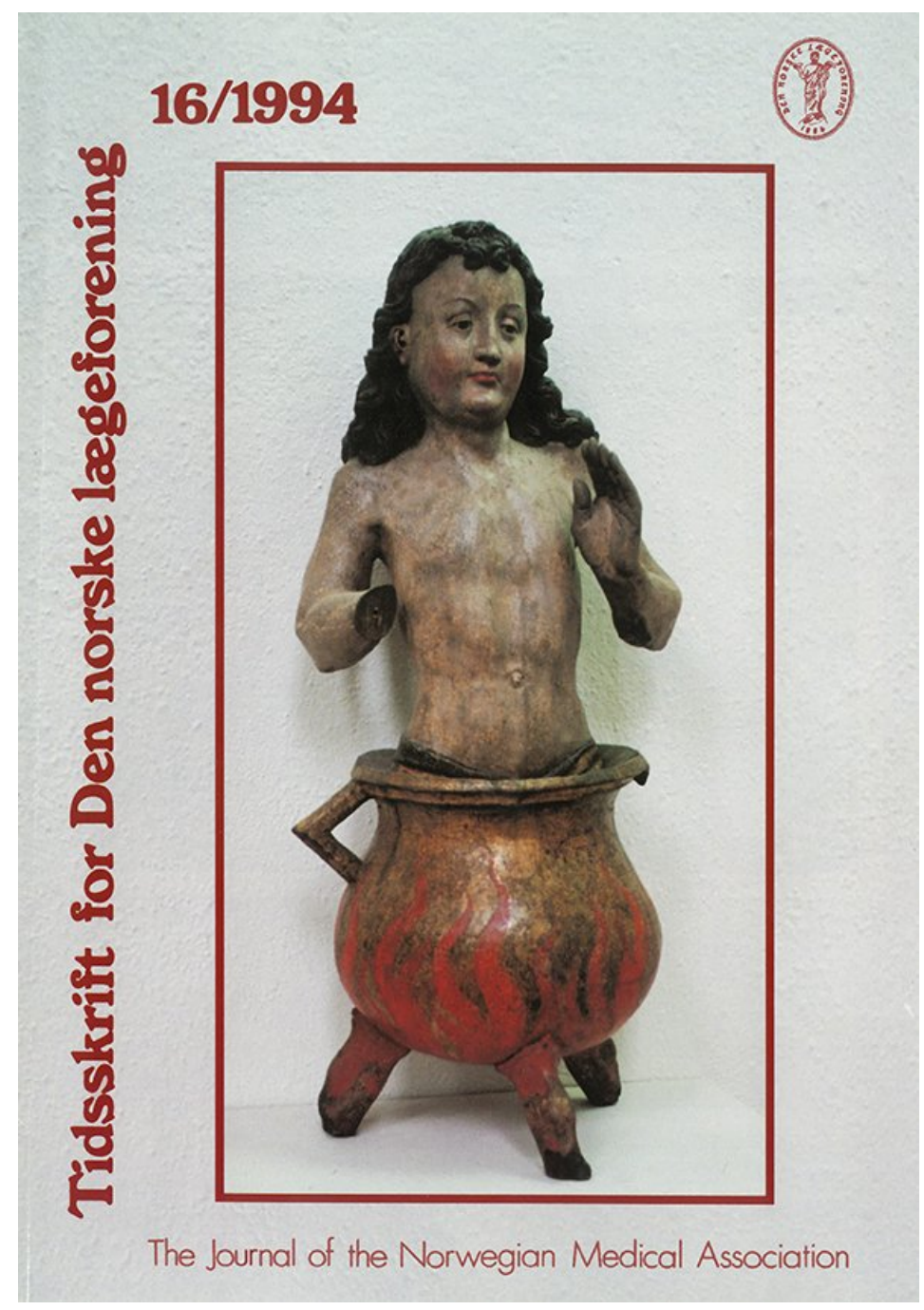

Blant helgenene er det noen som er tillagt en særlig evne til å kunne hjelpe ved sykdom, nød og fare. Dette er en gruppe på 14-14 er to ganger sju, og sju er et hellig tall. Denne senere innarbeidede tradisjonen antas å ha oppstått uformelt i Tyskland på 13oo-tallet og kom til Norden omkring 1500.

Dyrkingen av nødhjelperhelgenene blandet seg imidlertid med lokal skikk og bruk, slik at det f.eks. kunne hende at gruppen ble på flere enn 14. Noen av helgenene er også mindre kjente og hadde ikke noen selvstendig plass. Nødhjelperne i Norden var Georg, Blasius, Erasmus, Panthaleon, Vitus, Kristoffer, Ægidius, Achatius, Dionysius, Cyriacus, Eustachius, Katarina av Alexandria, Margareta og Barbara, altså 14. Magnus nevnes stundom i tillegg, ev. erstattet med Maria, og også Dorothea. Det er tvil om hvorvidt Leonardus og Rochus hører med i nødhjelpergruppen, selv om deres navn også forekommer.

Han ble drept sammen med Modestus, sin lege, og Crescentia, sin fostermor

Forsidebildet viser et eksempel på en av nødhjelperne, St. Vitus eller St. Veit. Trefiguren er skåret i lindetre, stammer fra Oberrhein-distriktet i Tyskland og kan dateres til første del av 1500-tallet. Vitus var fra Sicilia og led martyrdøden under keiser Diokletians

kristenforfølgelser, sannsynligvis i år 303. Han ble drept sammen med Modestus, sin lege, og Crescentia, sin fostermor. Legenden gjengis imidlertid noe forskjellig, og det sies også at han overlevde på mirakuløst vis.

Vitus skal ha blitt kokt levende i tjære, og det er gjerne slik han blir avbildet. Han kan dessuten være fremstilt med en hane eller en bok som attributt og være omgitt av Modestus og Crescentia som har palmeblader i hendene.

St. Vitus ble antatt å kunne tilbes for å få hjelp mot sykdomstilstander der det forekom ufrivillige bevegelser, muskelrykninger e.l. av en eller annen årsak. Derav følger sykdomsbetegnelsen St. Veitsdans. Denne er i Norge av særlig interesse i forbindelse med 
Huntingtons chorea, Setedalsrykkja, men det er en annen historie.

Øivind Larsen

Publisert: 11. januar 2021. Tidsskr Nor Legeforen. DOI: 10.4045/tidsskr.20.0935

(C) Tidsskrift for Den norske legeforening 2020. Lastet ned fra tidsskriftet.no 